\title{
Shigella boydii Bacteremia in an Ederly Patient with No Underlying Disease
}

\author{
Kwang-Sook Woo, Jae-Lim Choi, Bo-Ram Kim, Ji-Eun Kim, \\ Kyeong-Hee Kim, Jeong-Man Kim, Jin-Yeong Han
}

\author{
Department of Laboratory Medicine, Dong-A University College of Medicine, Busan, Korea
}

Shigella bacteremia is rare, occurring mainly in children. Shigella species often cause diarrhea or gastrointestinal inflammation in humans and are rarely associated with bacteremia. This report describes an unusual case of Shigella boydii bacteremia in an 84-year-old patient visiting our hospital after experiencing nausea, vomiting, and febrile sensation for 2 days. Peripheral blood cultures revealed $S$. boydii and $16 S$ rDNA sequence analysis produced the same result. However, the organism was not isolated from the patient's stool. She was started on ciprofloxacin, to which this organism is sensitive, and was subsequently discharged with instructions to complete a 14-day course of ciprofloxacin. Shigellosis is usually a self-limiting enteric disease. However, in contrast to its isolation from both blood and stool, isolation of the organism from blood only is associated with a high mortality rate. As is frequently pointed out, blood cultures should be obtained from elderly or immunocompromised patients with acute febrile gastroenteritis to detect infection caused by enteric pathogens, including Shigella. (Ann Clin Microbiol 2014; 17:20-22)

Key Words: Bacteremia, Blood cultures, Shigella boydii

\section{INTRODUCTION}

Shigella bacteremia is rare, occurring mainly in children. Shigellosis is usually a self-limiting disease, involves only the gut $[1,2]$. Shigellosis is transmitted by the fecal-oral route, and has an incubation time of from 12 hours to 1 week. Resolution of symptoms is expected within 1 week in most cases with Shigella dysentery, and usually only supportive care is required [3]. We have experienced adult patient with Shigella bacteremia and we aim to describe about Shigella bacteremia.

\section{CASE REPORT}

A 84-year-old woman visited emergency room after experiencing nausea, vomiting and febrile sensation for 2 days. Shehad no underlying disease and recent weight loss. Her heart rate was $96 / \mathrm{min}$, respiratory rate was $20 / \mathrm{min}$, body temperature was $37.5^{\circ} \mathrm{C}$ and blood pressure was $120 / 80 \mathrm{mmHg}$ on examina- tion. She had taken herbal medication for the past 3 months. No pathologic finding was found on her physical examination. On suspicion of drug-induced toxic hepatitis, routine laboratory investigations were done. At the same time, two sets of blood cultures were also ordered to evaluate systemic infection. All dermatologic and other systemic examinations were normal. Results of the laboratory tests were as follows: ALT $221 \mathrm{IU} / \mathrm{L}$, AST $201 \mathrm{IU} / \mathrm{L}$, ALP 369 IU/L, LDH 799 IU/L, total bilirubin $3.7 \mathrm{mg} / \mathrm{dL}$, WBC $20.62 \times 10^{3}$ cells/ $\mu \mathrm{L}(89.4 \%$ segmented neutrophils, $4.3 \%$ lymphocytes, $6.2 \%$ monocytes, and $0.1 \%$ basophils), C-reactive protein $11.3 \mathrm{mg} / \mathrm{dL}$, and procalcitonin 13.30 $\mathrm{ng} / \mathrm{mL}$. Abdominal CT and US were performed and acute hepatopathy was assumed. After that, the patient were stopped taking herbal medication and the serum ALT, AST, ALP and total bilirubin level were decreased, but fever was sustained. On hospitalization day (HD) 1, two sets of blood cultures were positive for gram negative bacilli after $19 \mathrm{~h}$ of incubation and antibiotic therapy with cefotaxime was initiated. A subsequent subculture

Received 17 April, 2013, Revised 29 November, 2013, Accepted 30 November, 2013

Correspondence: Jin-Yeong Han, Department of Laboratory Medicine, Dong-A University College of Medicine, 1 Dongdaesindong 3-ga, Seo-gu, Busan 602-715, Korea. (Tel) 82-51-240-5323, (Fax) 82-51-255-9366, (E-mail) jyhan@dau.ac.kr

(c) The Korean Society of Clinical Microbiology.

(a) This is an Open Access article distributed under the terms of the Creative Commons Attribution Non-Commercial License (http://creativecommons.org/licenses/by-nc/3.0) which permits unrestricted non-commercial use, distribution, and reproduction in any medium, provided the original work is properly cited. 
of the blood isolate on MacConkey agar grew a non-lactose-fermenting, gram-negative bacillus. The isolate was oxidase negative and nonmotile. Stool culture was conducted on hospitalization day (HD) 3. But the organism was not isolated from stool because of delay of sample acquisition during hospitalization. Fever was still sustained. On HD 4, the isolate was identified as Shigella sonnei with commercial identification systems by VITEK 2 instrument (bioMérieux, Marcy-1'Etoile, France): the Vitek Gram Negative Identification. However, serogrouping with slide agglutination test (Denka Seiken Co. Ltd., Tokyo, Japan) revealed group $\mathrm{C}$. The culture results were then compared to those obtained with the commercial 16S rDNA sequencing (Macrogen, Seoul, Korea), for which 2 primers were used: 518F (5'-CCAGCAGCCGCGGTAATACG-3') and 800R (5'-TACCAGGGTATCTAATCC-3'). The sequence thus obtained $(1,488 \mathrm{bp})$ was compared with published sequences in the GenBank database by using the basic local alignment search tooln (BLASTn) algorithm (www.ncbi.nlm.nih.gov/blast), and the isolate showed $94.7 \%$ similarity to $S$. boydii and $94.0 \%$ to Shigella spp. that was insufficient for definite identification. Also, 16S rDNA sequencing does not resolve well within the genus level. Then, repeated identification tests were performed by VITEK 2 system and other commercial identification system using API 20E identification system (bioMérieux). The isolate was identified to $S$. boydii with use of conventional biochemical methods, serogrouping, and 2 commercial identification systems: the Vitek Gram Negative Identification Card (identity probability, 99\%), API 20E identification system (identity, 99\%).

The pathogen's antimicrobial susceptibility was initially determined by the VITEK 2 AST N131 card (bioMérieux). The isolate was resistant to gentamicin and cefazolin, while it was sensitive to ampicillin, ciprofloxacin and trimethoprim-sulphamethoxazole. She was started on ciprofloxacin as these organisms were sensitive to this agent and the fever subsided on day 4. She was discharged in a stable condition 7 days after admission with plans to complete a 14 day course of ciprofloxacin.

\section{DISCUSSION}

Shigella spp. are gram-negative, nonsporulating, rod-shaped bacteria that belong to the family Enterobacteriaceae. Four species exist (S. dysenteriae (Serogroup A), S. flexneri (B), S. boydii (C), and S. sonnei (D)). The diagnosis of Shigellosisis is made by isolating the organism from samples submitted for culture. Because of groups A, B and C are phenotypically sim- ilar, diagnosis for shigellosis are made by both biochemical tests and serologic typing by slide agglutination test. Shigella spp. often cause diarrhea or gastrointestinal inflammation in humans and are rarely associated with bacteremia [1,2]. Symptoms of infection include watery, often bloody, diarrhea, abdominal pain/cramps, and fever. Even though bacteremia by Shigella spp. was rare, it occurs usually in malnourished children and neonates and the most common causative organism is $S$. flexneri [1,2,4]. From 1989 to 2002 in the US, only $1.6 \%$ of 208,368 laboratory-confirmed Shigella infections reported to the Centers for Disease Control and Prevention were caused by S. boydii, and only $0.25 \%$ of these isolates were recovered from blood cultures [5]. S. boydii bacteremia is very rare in Korea. Only a small number of adult cases of bacteremia by Shigella spp. has been reported and most patients were immunosuppressed or had underlying diseases in Korea [4]. Infection is usually self-limiting, requires supportive care with fluid and electrolyte replacement and does not result in long-term sequelae [3,6]. But children and immunocompromised patients may experience significant morbidity and mortality [1]. Therefore, the use of antibiotics is recommended and treatment options include fluoroquinolones, ceftriaxone and other agents such as azithromycin and trimethoprim/sulfamethoxazole [1]. In case of Shigella bacteremia, isolation of the organism from blood only was also known to be associated with a high mortality rate, in contrast to its isolation both from blood and stool [1].

In our case, $S$. boydii, a rare cause of bacteremia was isolated in an adult patient. Though initial serologic and biochemical test by VITEK 2 showed different results, repeated test results by VITEK 2 and other commercial system were consistent with $S$. boydii. The elderly patient with fever, abdominal pain, nausea and vomiting was diagnosed accurately. The patient showed a good response to treatment in contrast to the literatures [1]. But it is difficult to make clear the difference among studies due to the organism was not isolated from stool because of delay of sample acquisition in this case.

In conclusion, we report an adult case of $S$. boydii bacteremia with good prognosis. As is frequently pointed out, blood as well as stool cultures should be obtained from elderly or immunocompromised patients with acute febrile gastroenteritis to detect enteric pathogens, including Shigella. An early and precise diagnosis is of prime importance because appropriate antibiotics in addition to supportive care can be life saving for such patients. 


\section{REFERENCES}

1. Morduchowicz G, Huminer D, Siegman-Igra Y, Drucker M, Block CS, Pitlik SD. Shigella bacteremia in adults. A report of five cases and review of the literature. Arch Intern Med 1987;147:2034-7.

2. Struelens MJ, Patte D, Kabir I, Salam A, Nath SK, Butler T. Shigella septicemia: prevalence, presentation, risk factors, and outcome. J Infect Dis 1985;152:784-90.

3. Barrett-Connor E and Connor JD. Extraintestinal manifestations of shigellosis. Am J Gastroenterol 1970;53:234-45.

4. Kang SY, Lee HJ, Suh JT. A case of Shigella sonnei bacteremia in an adult. Korean J Clin Pathol 2001;21:183-6.

5. Gupta A, Polyak CS, Bishop RD, Sobel J, Mintz ED. Laboratoryconfirmed shigellosis in the United States, 1989-2002: epidemiologic trends and patterns. Clin Infect Dis 2004;38:1372-7.

6. Markham KB, Backes C Jr, Samuels P. Bacteremia and intrauterine infection with Shigella sonnei in a pregnant woman with AIDS. Arch Gynecol Obstet 2012;286:799-801.

=국문초록=

\title{
기저질환이 없는 노인환자에서의 Shigella boydii 균혈증
}

\author{
동아대학교 의과대학 진담검사의학교실
}

우광숙, 최재림, 김보람, 김지은, 김경희, 김정만, 한진영

이질균에 의한 균혈증은 극히 드물며 주로 소아에서 발생한다. 이질균은 주로 설사나 위장관에 국한 된 염증을 일으키며 균혈증은 매우 드물다. 본 증례에서는 2일간의 오심, 구토, 열감을 주소로 내원한 84세 환자에서 Shigella boydii에 의한 균혈증을 서술하고 있다. 말초 혈액 배양 검사에서 S. boydii가 분리되었고 $16 \mathrm{~S} \mathrm{rDNA}$ 염기서열분석에서도 동일 소견을 보였다. 그러나 환자의 대변세균배양 검사에서는 균이 분리되지 안았다. 환자는 감수성을 보인 ciprofloxacin으로 치료를 시작하였고 14 일 과정의 ciprofloxacin 치료를 계속 하는 방침 하에 퇴원하였다. 이질균에 의한 감염증은 보통 자가 회복 장질환을 일으킨다. 하지만 대변과 혈액에서 동시에 분리되는 경우와는 다르게 혈액에서만 분리되는 경우 높은 치사율 과 관련이 있다고 알려져 있다. 따라서 급성 열성 위장관염을 주소로 내원한 면역 저하 환자나 노인에서는 Shigella 등의 병원균을 검출을 위한 혈액 배양이 꼭 필요하다. [Ann Clin Microbiol 2014;17:20-22]

교신저자 : 한진영, 602-715, 부산광역시 서구 동대신동 3 가 1 번지

동아대학교 의과대학 진담검사의학교실

Tel: 051-240-5323, Fax: 051-255-9366

E-mail: jyhan@dau.ac.kr 